\title{
The Distribution Strategy Of A Representative Fair Trade Organization In Korea: The Case Of Beautiful Coffee
}

\author{
Hye-Jeong Cho, SungKyunKwan University, Korea \\ Kyung-hee Kim, SungKyunKwan University, Korea \\ Sung-Min Ryu, SungKyunKwan University, Korea \\ Chul Woo Moon ${ }^{1}$, SungKyunKwan University, Korea
}

\begin{abstract}
This case study analyzes the distribution strategy of Beautiful Coffee, a leading fair trade organization in Korea. Because of their focus on matters of public interest, fair trade organizations often face financial difficulties, and such difficulties can limit their growth and force them to pursue differentiated distribution strategies. The results indicate that Beautiful Coffee can serve as a good role model for fair trade organizations and have important practical implications for firms pursuing sustainable growth as a social enterprise.
\end{abstract}

Keywords: Fair Trade; Social Enterprise; Coffee; Beautiful Coffee; Fair Trade Distribution Strategy

\section{INTRODUCTION}

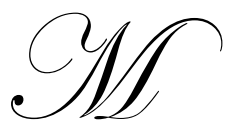

ore than two billon cups of coffee are consumed each day worldwide, and reflecting this, the specialty coffee market in Korea has grown rapidly in the last few decades. Following oil, coffee ranks second in terms of the volume of international trade. However, according to a special documentary by SBS (Coffee Hunter, ${ }^{2} 2010$ ), only $1 \%$ of the price of a cup of coffee goes to coffee producers, whereas the remaining $99 \%$, to big coffee chains and distributors. Given the prevailing prices of a cup of coffee in large cities such as London, Toronto, Sydney, and New York, a typical bag of coffee (approximately $50 \mathrm{~kg}$ ) produced in developing countries is worth approximately USD 13,000, but coffee producers see only about $0.006 \%$ (about 0.8 cents) of that money (Ransom \& Jang, 2007). That is, although large amounts of coffee are sent to developed countries, but coffee producers in developing countries derive little benefit from coffee trade.

The purpose of fair trade is to ensure that producers in developing countries are provided with appropriate rights and profits and to offer consumers in developed countries higher-quality coffee as a result. Beautiful Coffee, the first company to engage in fair trade in Korea, is the only profitable fair trade firm in Korea. Beautiful Store, the parent of Beautiful Coffee, is also a social enterprise (an organization employing capitalistic principles to achieve philanthropic objectives). Beautiful Store strives to spread fair trade throughout Korean society by acting more like an NGO than a for-profit firm.

Beautiful Coffee's marketing practices ensure appropriate rights for coffee producers through fair trade. Such marketing practices are different from typical marketing practices of firms seeking to maximize benefits. In particular, Beautiful Coffee's distribution strategy differs from that of other coffee firms. For example, large distributors, which typically have an imbalanced power relationship with small manufacturers, offer Beautiful Coffee favorable sales commissions and treat it differently from other small manufacturers. This is possible because Beautiful Coffee takes the moral high ground by observing fair trade. The purpose of this study is to determine the

\footnotetext{
${ }^{1}$ Corresponding author

${ }^{2}$ Coffee Hunter is a documentary film made by SBS, one of Korean broadcastings
} 
appropriate distribution strategies for fair trade products by examining the unique distribution strategy of Beautiful Coffee.

\section{FAIR TRADE AND SOCIAL ENTERPRISES}

\section{Social Enterprises}

Social enterprises lie somewhere between for-profit and non-profit organizations, that is, they pursue social objectives while making profits (Dart, 2004). These organizations deliver a diverse range of welfare or local services, and occasionally, they directly involve disadvantaged individuals in economic activity to improve their quality of life (Ohana \& Meyer, 2010). In recent years, the objectives of social enterprises have varied in terms of fair trade, and regional development, among others. In contrast to for-profit organizations, social enterprises strive to provide social services and create job opportunities for disadvantaged individuals. Korea has several social enterprises. For example, We Can is a cookie manufacturer employing mentally disabled individuals; Noridan is an organization producing musical instruments using recycled products and providing music for the neglected; and Dongchun Cap is a cap manufacturer employing individuals various disabilities (www.socialenterprise.go.kr).

\section{Fair Trade}

IFAT (International Fair Trade Association) suggests 9 standards that the members should follow. "These standards are concerned with reaching the economically disadvantaged, transparency and accountability, capacity building, promoting Fair Trade, improving the situation of women, child labour, working conditions, the environment and the payment of a fair price" (http://www.ecofashionworld.com) In other words, fair trade helps producers to establish a foundation for economic independence by providing producers with appropriate profits and consumers with ethically produced products (Madeley \& Litvinoff, 2007)

Beautiful Coffee adopted fair trade in 2003. Following its lead, some civic groups, cooperatives, and individual business entities have imported fair trade products, but their fair trade activity remains in the early stages. Table 1 shows the representative entities engaging in fair trade in Korea. In recent years, consumers have been paying more attention to "ethical consumption," and thus, the number of events and products related to fair trade has increased sharply. For example, Shinsegae Department Store recently sponsored an exhibit for fair trade products, and some distributors have established fair trade departments. These trends reflect the increasing social expectation and interest with respect to fair trade. In reality, however, there is a lack of awareness of the importance of fair trade in Korea.

Table 1: Representative Korean Social Enterprises

\begin{tabular}{|l|l|}
\hline \multicolumn{1}{|c|}{ Social Enterprise } & \multicolumn{1}{c|}{ Characteristics } \\
\hline Beautiful Store & $\begin{array}{l}\text { Beautiful Store currently runs charity shop for recycling and conducts many activities such as } \\
\text { public campaign and charitable activity promoting changes of society. }\end{array}$ \\
\hline Dure Cooperation & $\begin{array}{l}\text { Dure Cooperation established APNet to import Muscovado sugar from Philippines and olive oil } \\
\text { from Palestine. }\end{array}$ \\
\hline YMCA & YMCA provides Peace Coffee \\
\hline Fairtrade Korea & Fairtrade Korea imports organic cotton fabrics from India and produces t-shirts, named Gru. \\
\hline iCOOP & iCOOP imports cacao mass from Colombia to produce chocolate \\
\hline
\end{tabular}

\section{Distribution Of Coffee}

Coffee is distributed through several steps. After coffee berries are harvested, they are processed through either the wet or dry process method. This processing is done at the farm where the berries are harvested or near the farm. After milling, the beans are roasted and sent to developed and developing countries worldwide.

From farmers to consumers, distribution of coffee takes many steps. Figure 1 summarizes the distribution of coffee from farmers to consumers. First, producers sell raw coffee beans to intermediaries who transport them to 
a processing plant. After processing, coffee is sent to local exporters who then sell it to international distributors. Roasting firms typically purchase coffee from these international distributors and sell coffee to retailers such as supermarkets, restaurants, and hotels, among others.

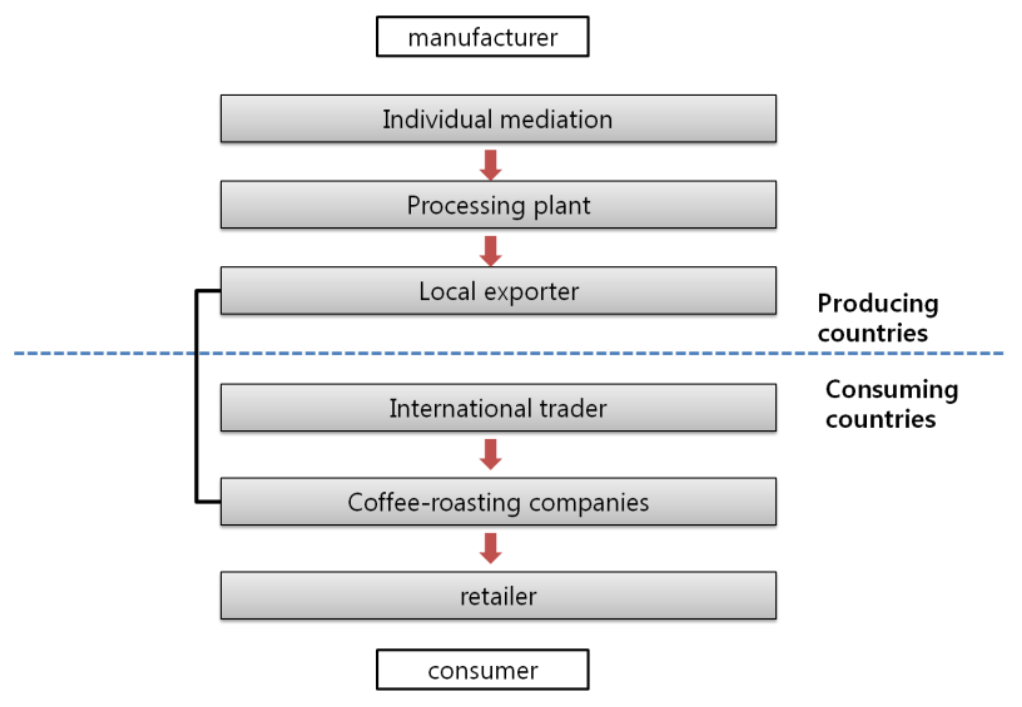

Figure 1: Distribution Of Coffee

The coffee industry has a clearly established distribution channel established mainly by buyers and suppliers. This distribution channel is governed by a small group of multinational firms and roasting firms. Like many other industries whose products employ international distribution channels, the coffee industry is characterized by an imbalanced distribution of power. Only four firms (including Neumann Coffee Group) account for approximately $40 \%$ of the entire international coffee trade. In addition, four firms (including Nestlé) account for approximately $45 \%$ of coffee roasting, which requires a high degree of centralization. Thus, coffee producers are at an enormous disadvantage as a result of this imbalance of power.

\section{Fair Trade Coffee Market}

The price of fair trade coffee is approximately half that of existing organic coffee, even though fair trade coffee is also organic. Fair trade coffee is sold at a relatively high price because of the premium in some developed markets. However, its price is generally lower than that of other coffee offerings in Korea. Thus, although social enterprises in Korea pay reasonable prices for coffee beans, they realize lower profits. In addition, to reduce selling and administrative expenses, these enterprises minimize their use of human resources and employ free technical advice from experts (Business Institute of SungKyunKwan University, 2010). Peace Coffee (managed by Korean YMCA) and other small fair trade coffee businesses are operating at a loss and facing serious financial difficulties because of a lack of a proper distribution channel.

\section{BEAUTIFUL COFFEE}

\section{Company Profile}

Beautiful Store is the first fair trade enterprise in Korea. It has grown by more than $100 \%$ each year since its launch of the "Present of the Himalayas" in 2002. Beautiful Coffee challenged to the very competitive Korean coffee market by opening four directly owned stores in 2009. It sells not only coffee but also chocolate and tea and tries to introduce other fair trade products. 
Just like Beautiful Store, Beautiful Coffee had some difficulty in the early stages. It incurred losses from 2002 to 2006 but became profitable in 2007, achieving KRW 26 million (USD 24,472) in net income. Through its continued efforts, it accounted for approximately $61 \%$ of the Korean fair trade coffee market as of 2008. In addition, it continues to add stores and promotes fair trade through press releases, events, conventions, and other activities. Table 2 shows the sales of Beautiful Coffee.

Table 2: Total Sales of Beautiful Store (2008 - 2011) (\$USD)

\begin{tabular}{|l|c|c|c|c|}
\hline Year & 2008 & 2009 & 2010 & First Half of 2011 \\
\hline Sales Amount & 880 million & 2 billion & 3 billion & 2 billion \\
\hline
\end{tabular}

\section{Marketing Strategy}

Target

Beautiful Coffee has no specific target market, that is, it targets anyone who can pay for its coffee. However, its mission is to make Korean society aware of the importance of fair trade, and thus, it does not target specific customers. In addition, although college students and employees in their twenties and thirties are likely to be aware of and have positive attitudes toward fair trade, housewives in their forties and fifties are the main customers, accounting for approximately $25 \%$ of total sales.

Beautiful Coffee does not impose ethical consumption on customers to increase its sales. The greatest advantage of Beautiful Coffee is not the fair trade itself but its freshly roasted coffee. When customers order coffee via an internet shopping mall, they receive coffee roasted the day before its order. Therefore, Beautiful Coffee targets those who really know how to enjoy coffee.

\section{Product Line}

As discussed earlier, Beautiful Coffee does not only impose ethical consumption on its customers to help coffee producers. Instead, they focus on the quality of coffee and challenge its competitors through high-quality management, organic products, and freshness. Beautiful Coffee's coffee products can be broadly classified into the following three categories based on the place of origin: the Himalayas (Asia), the Andes (South America), and Kilimanjaro (Africa). The firm has no plans to add new brands, that is, it focuses only on expanding its existing product line.

Beautiful Coffee also offers tea products, and more recently, it has launched cacao products, which represent one of the most unfair trade products. It has achieved considerable success with the first cacao products: chocolate and hot chocolate. These products have been well received and are particularly popular on Valentine's Day. Based on this success, Beautiful Coffee plans to offer olive oil, sugar, and other products.

According to a joint survey by Beautiful Coffee and TNS Research International, only $13.4 \%$ of the respondents recognized Beautiful Coffee. Although Beautiful Coffee is well known or frequented by people in Seoul, its brand awareness is generally low in other cities. Nevertheless, approximately $50 \%$ of the respondents had intentions to purchase of Beautiful Coffee products, indicating consumers' favorable attitudes toward Beautiful Coffee. In addition, $54.1 \%$ wanted to purchase its products to participate in fair trade, and $19 \%$ liked its environment-friendly organic products.

Noteworthy is the consumer's recognition of the high quality of fair trade products. This suggests that Beautiful Coffee must not only supply high-quality products but also foster consumers' interest in fair trade products to remain profitable. That is, to achieve their social objectives and maintain their financial success, Beautiful Coffee should equate Beautiful Coffee with high-quality products and thus with fair trade coffee. 
Price

Although Beautiful Coffee offers organic products, its prices are lower than those of competitors. In general, Beautiful Coffee has not raised their prices, even though the costs of raw materials and transportation have increased in recent years. In 2010, it raised its prices slightly, but its prices have remained considerably lower than those of others. Despite its unwillingness to raise prices, it has continued to provide its customers with high-quality products.

Beautiful Coffee does not offer price discounts to its customers and large distributors. "Buy one, get one free" is a common type of discount offered by large distributors, but Beautiful Coffee offers no such discounts. Manufacturers typically cooperate with distributors through price discounts and financial assistance to acquire good shelf space or to reduce their inventory. However, Beautiful Coffee does not offer discounts for volume purchases. Although its policy of "no price discounts" is to provide producers with higher profits, it is a reasonable policy because of the characteristics of high-quality organic products.

Table 3 shows the prices of Beautiful Coffee and competing products. Although the prices of Beautiful Coffee products do not vary across distribution channels, those of Hikoco, the first specialty coffee firm to acquire the ISO 9002 certification, vary across distributors. Some drip coffee brands supplied by large firms are sold at very low prices to compete with Beautiful Coffee. With the expansion of fair trade markets, some large domestic firms are targeting the fair trade coffee market, and thus, Beautiful Coffee should prepare for increased competition.

Table 3: Beautiful Coffee And Retail Price Of The Competitive Products

\begin{tabular}{|c|c|c|}
\hline \multirow{3}{*}{$\begin{array}{l}\text { Lotte } \\
\text { Department store }\end{array}$} & Beautiful coffee & $\begin{array}{l}\text { Single bag } 12 \mathrm{~T} 5,000 \text { won } \\
\text { Coffee beans } 200 \mathrm{~g} 10,000 \text { won }\end{array}$ \\
\hline & FNC & Coffee beans $100 \mathrm{~g} 13,500$ won \\
\hline & hikoco & Coffee bean set $600 \mathrm{~g} 64.000$ won \\
\hline \multirow{3}{*}{ Homeplus } & Beautiful coffee & $\begin{array}{l}\text { Single bag } 12 \mathrm{~T} 5,100 \text { won } \\
\text { Coffee beans } 200 \mathrm{~g} 10,150 \text { won }\end{array}$ \\
\hline & Lotte chilsung Cantata & Drip bag $12 \mathrm{~T} 3,600$ won \\
\hline & hikoco & Coffee beans $250 \mathrm{~g} 13,400$ won \\
\hline \multirow[t]{3}{*}{ G Market } & Beautiful coffee & $\begin{array}{l}\text { Single bag } 12 \mathrm{~T} 6,000 \mathrm{won} / 5,100 \mathrm{won} \\
\text { Coffee beans } 200 \mathrm{~g} 10,000 \text { won/10,150won/12,000won } \\
\text { Drip bag } 10 \mathrm{~T} 8,000 \text { won }\end{array}$ \\
\hline & Lavita coffee & Coffee beans $200 \mathrm{~g} 19,000$ won \\
\hline & starbucks & Coffee beans $907 \mathrm{~g} 20,290$ won/20,690won/20,480won etc \\
\hline \multirow[t]{3}{*}{11 st } & Beautiful coffee & $\begin{array}{l}\text { Single bag } 12 \mathrm{~T} 5,000 \mathrm{won} / 5,940 \mathrm{won} / 6,000 \mathrm{won} \\
\text { Coffee beans } 200 \mathrm{~g} 10,000 \mathrm{won} / 10,150 \mathrm{won} / 12,000 \mathrm{won} \\
\text { Drip bag } 10 \mathrm{~T} 8,000 \mathrm{won}\end{array}$ \\
\hline & Lavita coffee & Coffee beans $200 \mathrm{~g} 19,000$ won \\
\hline & starbucks & Coffee beans $907 \mathrm{~g} 19,650 \mathrm{won} / 19,900 \mathrm{won} / 20,290 \mathrm{won} / 23,900 \mathrm{won}$ etc \\
\hline
\end{tabular}

\section{Promotion}

Beautiful Coffee's promotion strategy differs from those of other firms. Beautiful Coffee does not offer price discounts or free products, although many distributors focus on such strategies. This is because Beautiful Coffee has maintained its "lowest-price policy." In addition, Beautiful Coffee does not offer coffee-tasting events or royalty programs (e.g., reward points). Further, Beautiful Coffee engages in no TV advertising. However, it does employ print advertising featuring a famous Korean singer. All the events it plans are carried out through donations, and all donated tickets are delivered to customers. In fact, according to the survey, customers recognize Beautiful Coffee through its public image. 


\section{Distribution Strategy}

Beautiful Coffee's distribution strategy was unsuccessful in the early stages. Because it is an NGO promoting fair trade, it did not engage in profit-oriented marketing activity. Instead, distributors interested in fair trade contacted Beautiful Coffee first to initiate the business.

The exploitation of coffee producers and unfair trade practices of firms have become a controversial issue. As a result, people have become more interested in fair trade coffee and news about the fair trade practices of Beautiful Coffee. The clear and fresh image of Beautiful Coffee, spread through various means, has attracted increasing attention from consumers. Thus, an increasing number of consumers have demanded Beautiful Coffee, and the distribution channel has become more diversified. Currently, Beautiful Coffee engages in a wide range of marketing activity to stress the importance of fair trade.

\section{Distinct Features Of The Distribution Strategy}

The distribution of coffee generally follows the "country of origin-trader-production/wholesale-coffee bean processing-retailer" path. During this stage, large firms often engage in unfair trade practices. Thus, the exploitation of producers and children in terms of labor and pay has been an important issue. In this regard, fair trade has emerged to address this exploitation and ensure the rights of producers.

Beautiful Coffee, as a social enterprise, has established cooperative relationships with its distribution partners. First, the distribution partners of Beautiful Coffee do not behave opportunistically or pursue their own interests. Instead, they share Beautiful Coffee's views and thus have transactional relationships, although the transaction amount is minimal. According to transaction cost theory (Williamson, 1985), distribution partners should be governed because they behave opportunistically whenever there is an opportunity to do so. However, Beautiful Coffee and its partners do not engage in opportunistic behaviors because they both focus on fair trade, which places great emphasis on morality. This has allowed Beautiful Coffee to maintain long-term distribution relationships. Thus, given that no study has examined the relationship between fair trade as a moral concept and long-term transactional relationships, Beautiful Coffee has unique distribution relationships.

In selecting its distribution partners, Beautiful Coffee has focused on specific qualifications reflecting social enterprises. Beautiful coffee realizes the importance of selecting right partners and thus considers various criteria. The most important criterion is whether a firm has intentions to engage in fair trade practices, followed by its reputation and image. If the image of a potential partner does not fit that of Beautiful Coffee, no relationship is formed. Such standards indicate the uniqueness of partnerships among fair trade organizations.

Finally, because of its nature as an NGO, Beautiful Coffee's distribution strategy is different from those of others in terms of slotting fees. Sales charges for normal brands are approximately $45 \%$ of the selling price; distribution costs/sales promotion fees are approximately 15-20\%; and manufacturing costs of instant coffee are less than 25\%. However, Beautiful Coffee is treated favorably in terms of slotting fees (Table 4).

Table 4: Beautiful Coffee's Selling Commission (At Large Distribution Channels / Excluding VAT)

\begin{tabular}{|l|c|c|c|c|}
\hline Distribution Channel & Homeplus & Lotte Mart & Family Mart & 7 -Eleven \\
\hline Commission & $26 \%$ & $29.7 \%$ & $30 \%$ & $30 \%$ \\
\hline
\end{tabular}

(source: Beautiful Coffee)

Sales charges play a critical role in the distribution of coffee. Guided by the mission statement "Greater hope to producers, greater enjoyment to consumers," Beautiful Coffee believes that its selling price based on production costs should be different from those of other coffee brands. Thus, there is a large difference between traditional charges required by distribution channels and production costs. Distributors generally pressure manufacturers to pay for sales charges and promotional fees, and force them to offer discounts and hold tasting events to attract customers to stores. Such conventional requirements generally lead to increased selling prices and 
hence place additional burdens on consumers, which is in contrast to fair trade practices. Therefore, Beautiful Coffee does not supply coffee to any distributor with unreasonable requirements. Given that manufactures typically endure such unfair requirements, Beautiful Coffee has a very distinctive relationship with powerful distributors.

\section{Distribution Channel}

As shown in Figure 2, 23.8\% of Beautiful Coffee's sales in 2009 came from major discount stores; $12.9 \%$, from direct stores; $12.4 \%$, from direct online stores; $9.6 \%$, from Beautiful Store outlets; $2.5 \%$, from convenience stores, and 38.8\%, from other outlets such as open markets and online shopping malls. Discount stores accounted for a large portion of sales because they had numerous branches across the country.

Beautiful Coffee employs diverse distribution channels to approach a wide range of consumers. However, because this strategy can lead to conflicts among various channels, Beautiful Coffee differentiates its products in terms of the package volume and the product mix for each distributor. This strategy takes into account the differences in target customers between distributors. For example, because convenience stores have limited shelf space, they require small packages. In addition, convenience store customers tend to show a strong individual consumption pattern and a fast turnover rate. Therefore, Beautiful Coffee provides single bags (12T) and drip bags (4T) made of freshly roasted coffee. On the other hand, Beautiful Coffee provides discount stores with large packages (single bags, 30T) because their customers are mainly those interested in bulk (lower) prices. Thus, Beautiful Coffee should develop a wider range of products by carefully considering the differences in the needs of customers across its distribution channels.

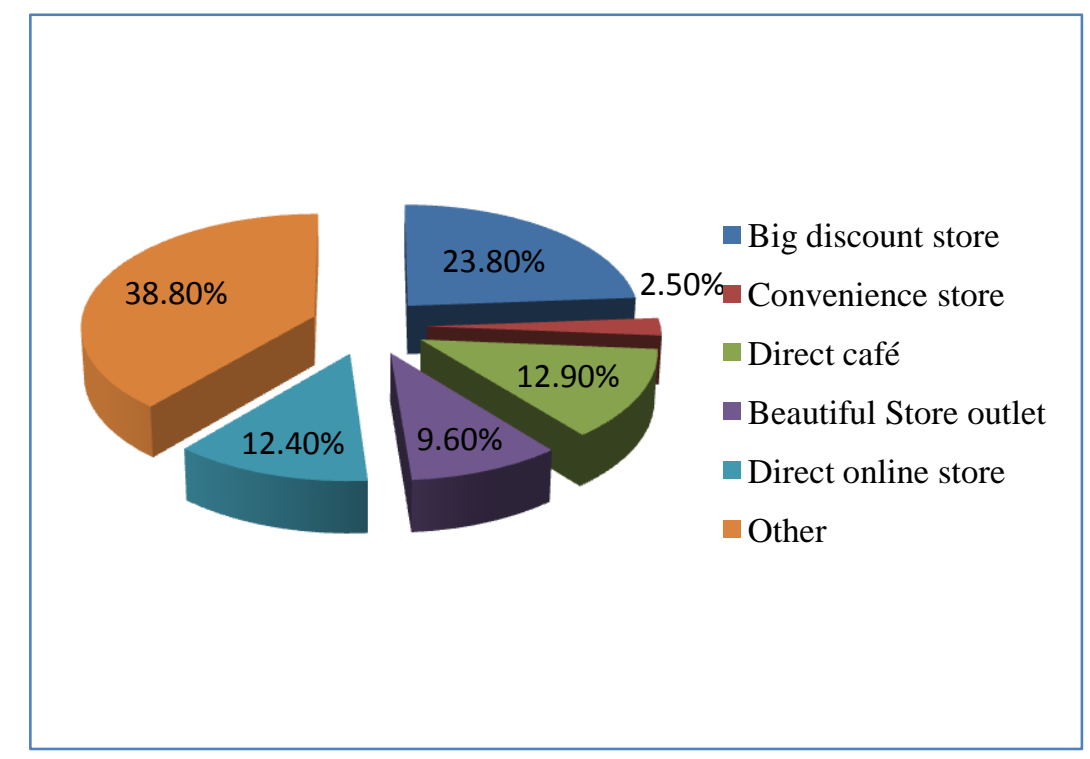

Figure 2: Total Sales By Distribution Channel In 2009 (Excluding VAT)

(source: Beautiful Coffee)

\section{1) Discount Store}

Beautiful Coffee had some difficulty finding distributors in the past because they resisted sending detailers and the coffee margin was very low. In addition, low brand awareness and sales charges limited its transactions with discount stores. In this regard, it was remarkable that Home Plus, one of the largest discount stores in Korea, decided to sell the "Present of the Himalayas" through its 33 branches. Given the increase in the number of consumers demanding fair trade coffee and the increasing attention paid to fair trade by firms, Beautiful Coffee products are 
now sold at Home Plus (112 branches) and Lotte Mart (66 branches). To prevent conflicts between distribution channels, Beautiful Coffee has sold the "Present of the Himalayas" through Home Plus and the "Present of the Andes" through Lotte Mart.

Beautiful Coffee stimulates consumer sentiment by using discount stores with nationwide networks and emphasizing that purchasing free trade coffee means donations for coffee producers. Its sales charges are lower than those of other firms, and its products are displayed with other coffee products, not with other fair trade products. This has increased sales for Beautiful Coffee. Beautiful Coffee's slotting fee is approximately $30 \%$, which is much lower than that for other products. Beautiful Coffee plans to provide coffee through E-Mart and GS Supermarket. EMart has sold Peace Coffee, which is the fair trade coffee offered by YMCA, since 2009 through 60 branches.

\section{Convenience Store}

Beautiful Coffee provides coffee through all branches of Seven Eleven and Family Mart. Seven Eleven was the first convenience store to sell fair trade coffee. It signed the "Supporting Fair Trade Agreement" in 2009, promising to donate $1 \%$ of Beautiful Coffee sales to promote fair trade. (Kim, 2009). At first, Beautiful Coffee provided the "Present of the Himalayas" and the "Present of the Andes" tea bags. With favorable responses to those products, Beautiful Coffee launched a private brand called "One Cup." Beautiful Coffee tea bags are more expensive than competing products but are more popular. The sales turnover in the last week of October 2009 was 5 times higher than that in the first week of its launch, and the turnover of the "One Cup" was 2.8 times that in the first week (Lee, 2009). Family Mart started to sell Beautiful Coffee since September 2009, and $73.2 \%$ of the total sales were sold for the first week.

One of the main disadvantages of being in convenience stores is that franchisees have considerable power to decide what to sell. That is, a franchisee may refuse to sell certain products that the franchisor decides to market. Therefore, franchisors have to persuade store owners to sell fair trade coffee. If their efforts fail, then consumers will have difficulty buying fair trade coffee through convenience stores. Thus, Beautiful Coffee should engage in franchisee-oriented marketing activity.

\section{3) Department Store}

As of 2011, the only department store carrying Beautiful Coffee is Lotte Department Store. Department store customers have considerable purchasing power, and thus, Beautiful Coffee has generated substantial sales through Lotte Department Store. However, sales charges are higher for department stores than for discount stores. For this reason, Beautiful Coffee discontinued its relationship with Galleria Department Store in 2010, which started in 2006.

For Lotte Department Store, Beautiful Coffee employs the shop-in-shop format through Orga, an environment-friendly store specializing in food products. The "Present of the Himalayas" acquires its organic certification from NASAA (National Association for Sustainable Agriculture Australia Limited) and is sold through Orga, which sells only organic food products. This certification has played an important role in attracting consumers (www.orga.co.kr).

Beautiful Coffee has attempted to expand its network of department stores because most department store customers have a taste for high-quality products and thus demand high-quality coffee. In the case of Shinsegae Department Store, based on favorable consumer responses to a fair trade products event, Beautiful Coffee plans to provide coffee through the fair trade corner placed on Shinsegae Department Store.

\section{4) Internet Retailing}

Internet retailing allows firms to interact directly with customers via the Internet and enables customers to purchase products or services, including coffee products, quickly and easily. Because freshness is very important in the distribution of coffee, the ability of the Internet to facilitate quick delivery is suitable for the distribution of coffee products. Thus, the Internet has been the most active distribution channel for coffee. In fact, fair trade coffee 
is traded most briskly through the Internet. Beautiful Coffee sells its products through online shopping malls and open markets. In addition, it directly manages an online shopping mall.

GS Shop was the first to sell Beautiful Coffee products. GS Shop signed an agreement supporting the independence of social enterprises with Beautiful Store and has sold Beautiful Coffee products through the "Real Love" corner, an online space only for products by social enterprises (Jang, 2010). In addition to the "Real Love" corner, Beautiful Coffee products are sold through various online shopping malls such as Yes 24, Aladdin, and $1300 \mathrm{~K}$.

To sell products through open markets, firms have to consult with merchandisers; emphasize the distinctiveness of their products; and maintain appropriate sales charges.

Beautiful Coffee's online shopping mall benefits its customers by providing them with fresh coffee. Therefore, its key customers are those looking for high-quality coffee or emphasizing freshness. One distinctive feature of Beautiful Coffee's online shopping mall is that there are no royalty programs such as discounts or reward points.

\section{5) Direct Store}

Beautiful Coffee is one of Beautiful Stores' fair trade departments, and thus, Beautiful Store is a direct distribution channel for Beautiful Coffee. Beautiful Store sells a wide range of fair trade brands and products and is thus not limited to Beautiful Coffee products.

Beautiful Coffee opened four directly managed cafés in Seoul through donations by consumers among others. Because the café is directly managed, the quality of its coffee can be easily controlled, and coffee is served at low prices.

\section{6) Franchise B2B}

Beautiful Coffee has contracts with franchisors for the sale of various coffee products. These products are all organic and sold under franchise brands. Through this arrangement, franchisors and franchisees divide the sales margin equally.

\section{7) Special Sales}

Beautiful Coffee takes part in special marketing events with important partners to promote fair trade coffee. For such events, product packages feature the name of the partner as well as that of Beautiful Coffee. In addition, leaflets containing promotional statements are used for promoting fair trade coffee, but no TV advertising is employed.

Hyundai Home Shopping was the first in the field to sell fair trade coffee twice. In the first broadcast, it sold the entire inventory (Jeong, 2009). Based on this success, CJ O Shopping sold Beautiful Coffee products in October 2010. More events are expected in the future, which should help expand the market.

In cooperation with Shinsaege Department Store, Beautiful Coffee organized a tasting event in which people donated what they wanted after tasting coffee. It used this event to increase people's awareness of fair trade coffee.

In addition, Beautiful Coffee has persuaded firms to use its coffee for their employees and report it in their CSR (corporate social responsibility) reports. Some large firms have organized "beautiful Saturday campaigns" with Beautiful Coffee. These events have provided Beautiful Coffee with opportunities to meet CSR managers and persuade them to use fair trade coffee. Further, Beautiful Coffee and Red Cross have offered coffee and chocolate for those donating blood. 
Through such linked campaigns, firms have improved their corporate image among those consumers who are familiar with fair trade, and in terms of those not familiar with fair trade, such campaigns have helped to increase their awareness of fair trade.

\section{CONCLUSION AND IMPLICATIONS}

Coffee has quickly become one of the most successful fair trade products, and its rapidly increasing size has influenced existing coffee markets. Coffee is considered a suitable fair trade product because it is purely a primary product. That is, coffee is almost free of additives, and thus, the production and distribution of coffee products are simpler than those of other products. For this reason, coffee is more suitable for fair trade than other products. Not only NGOs but also for-profit firms have entered fair trade markets, and this trend is expected to continue. Thus, it is expected that large firms in Korea (e.g., Lotte) will enter the fair trade coffee market in the near future.

This study investigates the marketing strategy of Beautiful Coffee, which has achieved considerable financial success while pursuing social objectives as the first social enterprise in Korea. The study contributes to the fair trade literature by providing an in-depth analysis of the unique distribution strategy of Beautiful Coffee, including the differences in its distribution strategy across its wide range of distributors.

Beautiful Coffee's marketing efforts focus mainly on "organic products," followed by "organic products at appropriate and competitive prices" and "ethical consumption," in that order. However, Beautiful Coffee is recognized only by fair trade instead of high-quality organic products. According to a joint survey by TNS International Research and Beautiful Coffee, only $13.4 \%$ of the respondents were aware of the Beautiful Coffee brand and $50 \%$ of those who had knowledge of the brand purchased the product because of its efforts to assist producers in underdeveloped countries. In this regard, given Korean consumers' considerable interest in organic products, Beautiful Coffee should position itself as a supplier of high-quality organic products and develop a new distribution strategy reflecting this approach.

Beautiful Coffee enjoys favorable sales charges from most distributors because it provides fair trade products. If other firms provide similar products, Beautiful Coffee is likely to face intense competition, and thus, it should prepare for this possibility by developing a distribution strategy reflecting the needs of each type of distributor. For example, if a discount store imposes the same level of sales charges on Beautiful Coffee, then it can no longer enjoy price competitiveness. In this case, other discount stores may also increase sales charges, further lowering Beautiful Coffee's price competitiveness.

All distributors currently sell exactly the same product line, which may provoke conflicts among the distributors. Thus, Beautiful Coffee should launch different product lines to differentiate between distributing channels. Most distributors currently offer 12 and 30 single bags ( $4 \mathrm{~g}$ ) under three brands (Himalayas, Andes, and Kilimanjaro) at similar prices. However, distributors typically want differentiated products to attract more customers. Thus, Beautiful Coffee should not provide exactly the same products if it wishes to establish better cooperative relationships with its distributors.

This study analyzes the distribution strategy of Beautiful Coffee, the most successful social enterprise in Korea, but distribution is only one of the four elements (4Ps) of the marketing mix. In this regard, further research should further investigate Beautiful Coffee by considering the other elements of the marketing mix.

\section{Case Questions}

1. What is the multi-channel approach? Why do firms take the multi-channel approach? Discuss the issues facing firms taking the multi-channel approach.

2. Discuss the problems associated with Beautiful Coffee's multi-channel approach. Providing all distributors with exactly the same products may lead to some problems. What are they?

3. How can Beautiful Coffee reduce the conflict that may arise between distributors?

4. How can Beautiful Coffee increase brand awareness? 


\section{Teaching Notes}

1. The multi-channel approach refers to a strategy using more than one distribution channel to deliver products and services to consumers. Using store and non-store retailing strategies, firms can provide their customers with information and opportunities to experience their products.

In the past, most firms used only one channel to distribute their products and services, but recently, market segment is accelerated which has allowed for the use of multiple distribution channels. For example, firms make simultaneous use of direct marketing, the Internet, and retailers to enter segmented markets.

The reason for shifting from a single-channel approach to a multi-channel approach is simple. It reduces the limitation of a single-channel approach and increases market coverage. In many markets, one channel covers less than half of total trade volume, and there are diverse types of customers. Therefore, a multichannel approach can satisfy a wide range of customers in segmented markets.

Some factors should be considered when taking a multi-channel approach. First, if a firm plans to use both a direct channel and a non-store channel, it should clearly differentiate between the two channels. For example, firms need to consider whether they will provide different products for the different channels, or provide same products to induce competition between the two channels.

Second, if a firm decides to provide overlapping products, it should determine whether they will have the same or different prices.

Third, if a firm wishes to minimize the competition between the two channels, it has to consider whether to make one channel to complement the other one. For example, it can allow customers to search information through the Internet but purchase through other channels. In this case, the Internet facilitates other channels. Firms have increasingly used the Internet to provide their customers with not only information but also products and services, and thus, the Internet has facilitated other distribution channels.

2. Beautiful Coffee's multi-channel approach may increase intra-brand competition. It currently provides all its distributors with very similar products because it has a limited product line. The only differentiation is the provision of different main items to each distributor. Thus, Beautiful Coffee risks intra-brand competition unless it can better address its limited product line as well as its strategy of offering the same prices.

Price discounts offered by Beautiful Coffee's online shopping mall are likely to provoke conflicts with its distributors, which sell the same products at full prices. Conflicts among distributors may weaken their trust in one another and thus damage their cooperative relationships.

Conflicts typically exist between firms because they are interdependent. By viewing the distribution channel as a social system in which the members exchange information and resources and are interdependent on one another, one can see that the members are individual entities pursuing their own interests. Therefore, conflicts between members are expected.

Conflicts between channel members are likely to reduce channel efficiency in the short run, and in particular, they can waste money, time, and effort. Conflicts arise when channel members believe that others are encroaching upon their interests and thus function independently. Therefore, such conflicts may make the whole distribution channel less efficient.

3. Beautiful Coffee can reduce conflicts between its distributors by providing different products. For example, Nike sells premium brands via the Internet and markets lower-priced brands through offline stores. In this way, it reduces conflicts by differentiating between different channels. Similarly, Beautiful Coffee can offer differentiated products based on the needs of each distribution channel. 
In addition, many firms, particularly video game and electronics firms, offer bundled products. Small retailers are more likely than large retailers to have difficulty obtaining price discounts based on the volume of their purchases. Thus, in the U.S. toy industry, large discount stores such as Toys'R'Us, Wal-Mart, and Target sell game packs and bags among others, separately, but small retailers are allowed to bundle such items. Similarly, Beautiful Coffee can bundle coffee with tumblers, mugs, or coffee grinders to reduce conflicts between different channels. This may also reduce intra-brand competition by providing a channelspecific product line for its multi-channel strategy.

4. Beautiful Coffee can use the Internet to provide information about the distribution network of large discount stores. For example, U.S. auto makers use the Internet as an implementing device for their existing dealer networks. Ford provides Ford owners with information on the company and traffic situations, among others, through Ford.com. In addition, customers can use this website for making reservations for car maintenance and repair. Similarly, Beautiful Coffee should use the Internet to provide its customers with detailed information on coffee. For example, it can provide videos showing how coffee is produced to increase their interest in coffee. In addition, it can provide roasting schedules to increase sales and brand awareness.

\section{AUTHOR INFORMATION}

Hye-Jeong, Cho is doctoral candidate of business at Sungkyunkwan University. She specializes in the areas of channels of distribution and global supply chain management. She has publication in Journal of Business Case Studies.

Kyunghee Kim is doctoral candidate of business at Sungkyunkwan University. She specializes in the area of channel of distribution and business-to-business marketing.

Sungmin Ryu is associate professor of school of business at Sungkyunkwan University. He specializes in the areas of channels of distribution, business-to-business marketing, and global supply chain management. He has publications in Industrial Marketing Management, Journal of Business Research, Organization Science, Journal of Business and Industrial Marketing, Journal of Business-to-Business Marketing, and Journal of Marketing Channels, and others. E-mail: smryu@skku.edu.

Chul Woo Moon is currently an associate professor of strategy at Sungkyunkwan University. His main research interests include corporate strategy, global competition and social enterprises. E-mail: cwmoon@skku.edu. Corresponding author.

\section{REFERENCES}

1. Business Institute of SungKyunKwan University(2010), "Risk, crisis \& successful management", SKKU Press, Seoul, Korea

2. Dart, R. (2004). "The legitimacy of social enterprise", Nonprofit Management and Leadership, Vol. 14 (4), PP411-424

3. Jeong, Seok-Yong(2009), "Home shopping begin selling the fair trade coffees.", Naeil Newspaper, 13, October

4. Lee Jeong-Yeon(2009)," Coffee viruses are spread through channel industries.”, Hankyoreh Newspaper, 06, November

5. Madeley, John and Miles Litvinoff (2007) "50 reasons to buy fair trade”, Motivebook Publish Co., Ltd., Seoul, Korea

6. Kim, Jung-Won(2009),’What is the social enterprise”, Arche Publish Co., Ltd., Seoul, Korea

7. Ohana, Marc, and Marylin Meyer (2010) "Should I stay or should I go? Investigating the intention to quit of the permanent staff in social enterprise", European Management Journal, Vol. 28(6), P. 441-454

8. Ransom, David, and Yun-jeong Jang (2007)“The No-nonsense Guide to Fair Trade", Ewho Publish Co., Ltd., Seoul, Korea

9. Williamson Oliver (1985), "The economic institutions of capitalism”, The Free Press, New York 
10. Coffee hunter(SBS Special documentary)

11. http://www.beautifulcoffee.com

12. http://www.orga.co.kr

13. http://www.socialenterprise.go.kr 


\section{NOTES}

